\title{
PERENCANAAN STRATEGIS SISTEM DAN TEKNOLOGI INFORMASI PADA STMIK - STIE MIKROSKIL MENGGUNAKAN METODE WARD \& PEPPARD
}

\author{
Chatrine Sylvia' $^{1)}$ dan Angela ${ }^{2)}$ \\ ${ }^{1,2}$ Jurusan Sistem Informasi, STMIK Mikroskil Medan \\ ${ }^{1,2} \mathrm{Jl}$. Thamrin No. 112, 124, 140, Medan, Sumatera Utara 20212 \\ E-mail : chatrine.sylvia@mikroskil.ac.id ${ }^{1)}$, angela.woen@mikroskil.ac.id ${ }^{2)}$
}

\begin{abstract}
ABSTRAK
Meningkatnya permintaan pasar akan pendidikan yang berkelanjutan namun dapat dilakukan dengan efektif dan efisien merupakan prioritas penting saat ini bagi perguruan tinggi dan mengakibatkan STMIK - STIE Mikroskil harus menetapkan strategi bisnis yang sesuai untuk memenuhi permintaan tersebut. Penetapan strategi bisnis ini berhubungan erat dengan strategi SI/ TI dimana penerapannya dalam penelitian ini berkaitan dengan penerapan pembelajaran jarak jauh dengan pemanfaatan penuh SI/ TI. Salah satu faktor yang telah diidentifikasi sebagai isu manajemen kritis adalah perencanaan strategis sistem informasi. Hal ini dianggap oleh banyak orang sebagai mekanisme terbaik untuk memastikan bahwa aktivitas SI/TI sesuai dengan aktivitas organisasi lainnya dan kebutuhannya yang terus berkembang. Perencanaan strategis sistem informasi yang dilakukan dalam penelitian ini adalah berdasarkan kerangka Ward \& Peppard (2002) yang mencakup metode dan teori analisis: value chain perusahaan, SWOT, analisis IT BSC, infrastruktur sistem, dan portofolio aplikasi.
\end{abstract}

Kata Kunci: Perencanaan Strategis, Ward \& Peppard, Value Chain, SWOT, IT BSC

\section{PENDAHULUAN}

Dalam industri usaha jasa, sistem informasi merupakan senjata yang paling penting dalam memenangkan ketatnya persaingan. Sebelum suatu teknologi ataupun sistem informasi dapat diterapkan dalam perusahaan, salah satu kunci utama yang menentukan adalah adanya perencanaan strategis sistem dan teknologi informasi. Hal ini dikarenakan perencanaan strategis sistem dan teknologi informasi yang matang dapat mendorong terwujudnya rencana dan pengembangan bisnis sehingga menghasilkan nilai tambah bagi perusahaan berupa keunggulan kompetitif dalam persaingan bisnis (Porter, 2011). Perencanaan strategis sistem informasi yang dilakukan dalam penelitian ini memanfaatkan metodologi Ward and Peppard, yang mempunyai tahap masukan berupa analisis lingkungan bisnis internal, analisis lingkungan bisnis eksternal, analisis lingkungan SI/TI internal, dan analisis lingkungan SI/TI eksternal. Hasil dari analisis ini akan mendefinisikan perencanaan strategis sistem informasi berupa strategi manajemen SI/TI, penerapan dan pemilihan teknologi informasi yang selaras dengan strategi bisnis STMIK - STIE Mikroskil.

Penelitian mengenai perencanaan sistem informasi strategis pendidikan di perguruan tinggi swasta kota Surakarta yang dilakukan oleh Wijiyanto dan Purwanto. Kegiatan analisis menggunakan analisis SWOT dan CSF. Hasil dari penelitian ini yaitu perencanaan sistem informasi strategis pendidikan yang diterapkan pada kota
Surakarta dimana didalamnya membahas mengenai desain masukan/keluaran, desain basis data yang disesuaikan dengan Entity Relationship Diagram (ERD), dan desain jaringan strategis yang dapat digunakan oleh pihak perguruan tinggi swasta dalam kegiatan pengambilan keputusan (Wijiyanto \& Purwanto, 2015). Penelitian yang dilakukan oleh Setiawan, Rosidi dan Boedijanto yang membahas mengenai perencaan sistem informasi strategis pada dinas kesehatan Kabupaten Kediri. Penelitian ini menggunakan analisis Value Chain, tabel Critical Success Factor dan McFarlan Strategic Grid. Perencanaan strategis dilakukan dengan mengacu pada analisis lingkungan internal dan analisis lingkungan eksternal dengan mempertimbangkan berbagai aspek nilai luhur yaitu strategi melayani masyarakat, pemberdayaan karyawan, dan kerja sama yang baik (Setiawan, Rosidi, \& Boedijanto, 2014). Selain itu, juga terdapat penelitian yang membahas mengenai perencanaan strategis sistem informasi smart campus untuk meningkatkan pelayanan di Politeknik Indonusa Surakarta. Penelitian ini dilakukan oleh Susena, Utami dan Sunyoto dimana penelitian ini memanfaatkan analisis PIECES, SWOT dan kerangka Ward dan Peppard. Hasil penelitian ini yaitu perencanaan strategis dan roadmap pengembangan sistem informasi smart campus, dimana terdapat 24 sistem informasi yang diprioritaskan untuk dikembangkan dan pengembangan sistem informasi untuk lima tahun kedepan (Susena, Utami, \& Sunyoto, 2015). 
Berikutnya merupakan penelitian yang dilakukan oleh Rida Indah Fariani dimana penelitian ini mengangkat judul analisa perencanaan strategis sistem informasi dan teknologi informasi (SI/TI) dengan menggunakan Framework Ward \& Peppard di Perguruan Tinggi ABC. Pada penelitian ini dilakukan penyusunan perencanaan strategis sistem informasi dengan memanfaatkan kerangka Ward dan Peppard yang dapat memastikan keselarasan strategi bisnis dengan strategi SI/TI. Penelitian ini merekomendasikan portofolio SI masa depan, analisis kesenjangan dan roadmap pengembangan SI/TI kedepannya (Fariani, 2014). Penelitian berikutnya dilakukan oleh Panca Anitasari yang membahas mengenai perencanaan strategis sistem informasi dalam meningkatkan daya saing sekolah pada SMK Komputer Mandiri Banjarbaru. Perencanaan strategis yang dilakukan bertujuan untuk meningkatkan kualitas lulusan dan menghadapi persaingan global dengan mengacu pada analisis Value Chain dan Five Force Porter. Hasil perencanaan strategis ini digambarkan menggunakan portofolio aplikasi McFarlan Strategic Grid (Anitasari, 2016). Selanjutnya merupakan penelitian oleh Ronny Faslah dan Abdul Haris yang berjudul perencanaan strategis sistem informasi dengan objek penelitiannya yaitu STMIK WICIDA. Penelitian ini memanfaatkan kerangka Ward dan Peppard dan menggunakan PEST, analisis Value Chain utuk menganalisis lingkungan internal dan eksternal bisnis, menggunakan McFarlan Strategic Grid untuk menganalisis lingkungan internal SI/TI. Rekomendasi dari penelitian ini yaitu perencanaan strategis sistem informasi yang dapat diterapkan pada STMIK WICIDA berdasarkan pada hasil analisis (Faslah \& Haris, 2017).

Penelitian ini juga menggunakan beberapa analisis yang dipakai pada penelitian terdahulu. Beberapa penelitian terdahulu menggunakan kerangka Ward dan Peppard untuk menyelaraskan strategi dan visi dari organisasi. Dengan adanya visi dan misi yang sangat berkaitan erat dengan basis SI/ TI, maka penetapan strategi SI/ TI sangat diperlukan untuk pencapaian visi dan misi tersebut. Hal ini didukung pula dengan ambisi untuk menerapkan program pembelajaran jarak jauh (online) yang terhubung $100 \%$ pada platform TI. STMIK STIE Mikroskil mempunyai misi dan ambisi untuk mengoptimalkan sumber daya lokal dalam memajukan masyarakat Indonesia melalui program pembelajaran jarak jauh bagi yang memiliki kendala waktu dan jarak untuk belajar secara langsung di kampus. STMIK - STIE Mikroskil menghadapi tantangan permintaan pembelajaran jarak jauh, ketersediaan dan kualitas hasil pembelajaran jarak jauh, presensi data mahasiswa pembelajaran jarak jauh, perubahan manajemen yang berkesinambungan, munculnya pemanfaatan teknologi, dan sebagainya. Mengacu pada tantangan tersebut, STMIK - STIE Mikroskil menciptakan strategi bisnis yang berkaitan dengan tugas dan fungsinya untuk menjamin kesinambungan dan konsistensi program penciptaan dan pengembangan kelas jarak jauh dan juga menjaga target yang ingin dicapai. Penelitian ini berfokus pada perencanaan strategis sistem informasi yang diselaraskan dengan strategi bisnis agar dapat membantu pihak perguruan tinggi untuk memenuhi tugas dan fungsinya.

STMIK - STIE Mikroskil belum menerapkan sistem informasi secara strategis, oleh karena itu sistem tidak berjalan optimal jika implementasi kelas jarak jauh tidak dipetakan sesuai kerangka yang ditunjuk dan laporan mahasiswa kelas jarak jauh tidak dilaporkan dalam satu platform. Hal ini dapat menyebabkan masalah dalam pengoperasiannya serta pengumpulan data dan pengolahannya. Solusinya yaitu dengan membuat Perencanaan Strategis SI dengan menganalisis situasi (sumber daya, infrastruktur), proses dan sistem pada STMIK - STIE Mikroskil, serta menyediakan solusi berupa manajemen pembelajaran berbasis web yang dapat mendukung pembelajaran jarak jauh, informasi bisnis, pengembangan aplikasi mobile, dan melakukan analisis gap. Terciptanya sistem informasi yang strategis menunjukkan perencanaan strategi manajemen SI / TI, strategi TI, strategi bisnis SI, serta portofolio aplikasi yang sesuai dengan tugas dan fungsi keberadaan lembaga pendidikan. Penelitian ini bertujuan untuk membuat rencana sistem informasi strategis yang dapat digunakan pada perguruan tinggi, sehingga bisa dimanfaatkan sebagai referensi pengembangan sistem informasi di STMIK - STIE Mikroskil.

\section{RUANG LINGKUP}

Ruang lingkup yang dibahas dalam penelitian ini mencakup:

1. Cakupan permasalahan dalam penelitian ini yaitu sistem tidak berjalan optimal jika implementasi kelas jarak jauh tidak dipetakan sesuai kerangka yang ditunjuk dan laporan mahasiswa kelas jarak jauh tidak dilaporkan dalam satu platform yang dapat menyebabkan masalah dalam pengoperasiannya serta pengumpulan data, dan pengolahannya.

2. Batasan-batasan dalam penelitian ini yaitu hanya membahas rencana strategis SI/TI namun tidak membahas rencana pengembangan Sumber Daya Manusia dan ketentuan lainnya.

\section{BAHAN DAN METODE}

Berikut merupakan landasan teori dan tahapan penelitian yang digunakan pada penelitian ini, yaitu sebagai berikut.

\subsection{Perencanaan Strategis SI/TI}

Perencanaan strategis SI/TI merupakan proses menganalisis dan mengidentifikasi portofolio aplikasi suatu sistem informasi yang berbasiskan pada komputer dimana sistem informasi ini digunakan untuk mendukung kegiatan organisasi dalam menerapkan rencana bisnis untuk mencapai tujuan bisnis. Perencanaan strategis SI/TI membahas mengenai kontribusi SI/TI terhadap kinerja bisnis dan pengaruhnya 
terhadap organisasi dalam mengimplementasikan tahapan-tahapan strategis. Perencanaan strategis SI/TI juga membahas mengenai alat, teknik, dan kerangka kerja yang cocok digunakan manajemen dalam menyelaraskan strategi SI/TI dengan strategi bisnis, serta mencari peluang untuk mengembangkan dan menerapkan teknologi yang lebih kreatif dan inovatif (Ward \& Peppard, 2002).

Perencanaan sistem strategis melibatkan alokasi berbagai sumber daya sistem di tingkat makro. Ada 4 (empat) alasan dilakukan perencanaan strategis yaitu sebagai berikut (Wijiyanto \& Purwanto, 2015).

1. Lebih baik ada rencana yang terus berubah daripada tidak ada rencana sama sekali. Perencanaan strategis menggambarkan jalur yang harus diikuti perusahaan untuk mencapai tujuan sistem informasinya yang akan disertai dengan banyaknya penyesuaian di tengah jalan.

2. Adanya perencanaan strategis akan mengurangi kekritisan komponen masalah yang muncul dalam pengembangan sistem. Perencanaan formal ini bertujuan merincikan kebutuhan pengguna dan membuat skala prioritas sehingga pihak manajemen dapat membuat keputusan yang lebih baik dengan mempertimbangkan berbagai kebutuhan di masa depan, mengidentifikasi masalah secara dini, dan juga mengantisipasi kebutuhan sebelum muncul gejala masalah.

3. Perencanaan strategis sistem memberikan kontrol otorisasi untuk pengembangan sistem. Rencana sistem strategis akan memastikan terlebih dahulu bahwa keputusan dalam mengembangkan suatu sistem memang selaras dengan tujuan perusahaan.
4. Perencanaan sistem strategis dapat memberikan hasil yang baik. Secara historis, perencanaan sistem telah terbukti mampu mengefektifkan biaya dalam mengelola berbagai proyek dan pengembangan sistem aplikasi.

\subsection{Metode Ward \& Peppard}

Pendekatan metodologi versi Ward and Peppard ini dimulai dari analisis kondisi bisnis dan investasi SI/TI yang sudah berjalan yang dinilai kurang efektif, lalu menganalisa kondisi bisnis eksternal sehingga dapat meningkatkan keunggulan kompetitif suatu organisasi. Penggunaan SI/TI dalam organisasi dianalis apakah hasilnya sudah maksimal untuk kemudian dibandingkan dengan kecenderungan penggunaan SI/TI di luar organisasi. Alasannya, karena sering kali kurang bermanfaatnya SI/TI bagi organisasi disebabkan oleh penggunaan SI/TI yang lebih berfokus pada teknologi, bukan pada kebutuhan bisnis organisasi (Ward \& Peppard, 2002).

Strategi SI/TI harus menjadi bagian yang terintegrasi dengan strategi bisnis, rencana bisnis dan implementasinya. Tujuan utama dari pengembangan strategi SI/TI adalah untuk mengidentifikasikan portofolio aplikasi yang memberikan nilai tambah sehingga berdampak strategis untuk jangka panjang. Sasaran implementasi SI/TI di dalam suatu organisasi memiliki tiga sasaran utama yaitu untuk memperbaiki efisiensi kerja, meningkatkan efektifitas manajemen untuk mendukung pengambilan keputusan dan meningkatkan daya saing ataupun keunggulan kompetitif organisasi (Ward \& Peppard, 2002).

Pendekatan ini dapat dilihat dari gambar 1 (Ward \& Peppard, 2002).

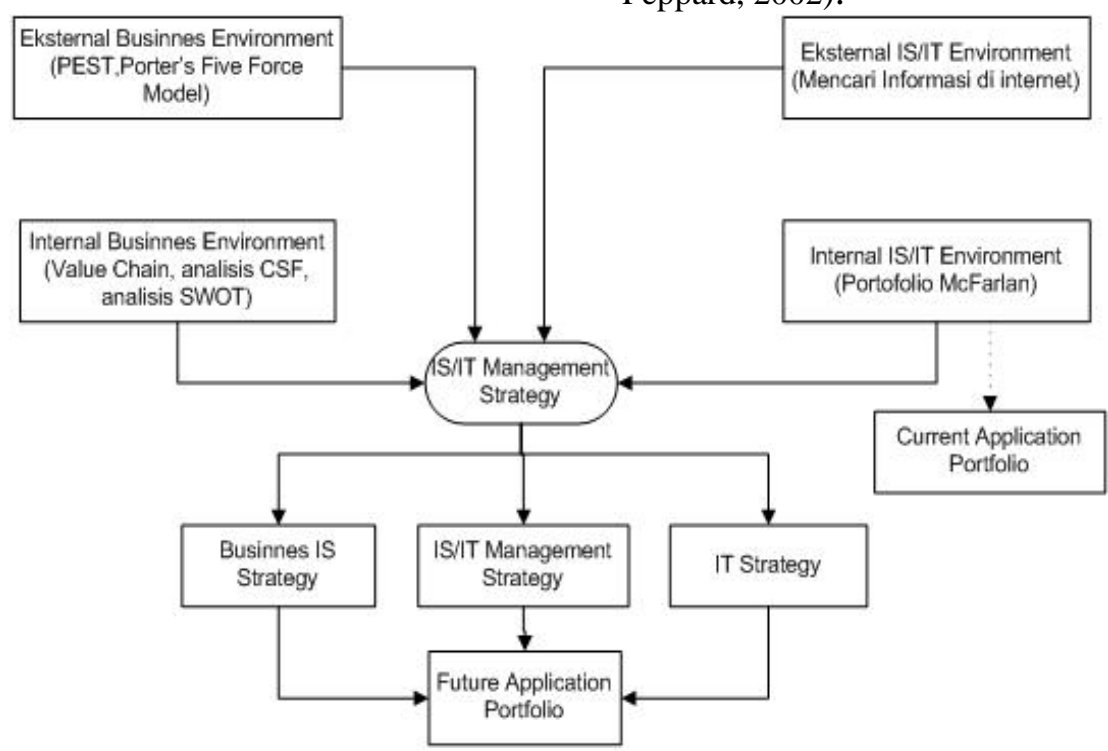

Gambar 1. Metode Ward \& Peppard 
Tahapan masukan dapat dibagi menjadi (Ward \& Peppard, 2002):

1. Analisis lingkungan bisnis internal, meliputi aspek strategi bisnis, sasaran, sumber daya, proses, serta budaya nilai-nilai bisnis yang terkandung dalam organisasi saat ini.

2. Analisis lingkungan bisnis eksternal, meliputi aspek ekonomi, industri, dan kondisi persaingan organisasi.

3. Analisis lingkungan SI/TI internal, meliputi kondisi SI/TI organisasi dari perspektif bisnis, tingkat kematangan (maturity) SI/TI, kontribusinya terhadap bisnis, skill sumber daya manusia yang dimiliki, infrastruktur dan sumber daya teknologi, termasuk juga dokumentasi perencanaan strategis dari SI/TI dalam organisasi saat ini.

4. Analisis lingkungan SI/TI eksternal, meliputi tren teknologi dan peluang penggunaannya, serta cara penggunaan SI/TI oleh pesaing, pemasok, dan pelanggan.

Sedangkan tahapan keluaran yang dilakukan untuk memperoleh suatu dokumen perencanaan strategis SI/TI yang berisi (Ward \& Peppard, 2002):

1. Strategi bisnis SI, yang membahas tentang cara setiap unit/fungsi bisnis dalam menggunakan SI/TI untuk mencapai sasaran bisnisnya, dokumentasi perencanaan strategis sistem informasi/aplikasi dan gambaran dari arsitektur informasi yang digunakan.

2. Strategi TI, meliputi strategi dan kebijakan yang diambil perusahaan untuk mengelola teknologi serta sumber daya manusia yang berkaitan dengan SI/TI.

3. Strategi Manajemen SI/TI, yang meliputi komponenkomponen umum untuk memastikan bahwa penerapan kebijakan SI/TI yang diterapkan lewat organisasi berjalan secara konsisten.

\subsection{Value Chain}

Value Chain memetakan seluruh proses bisnis atau aktivitas dalam organisasi menjadi 2 (dua) kategori aktivitas, antara lain aktivitas utama (primary activities) dan aktivitas pendukung (support activities). Hal ini mengacu pada dokumen yang merincikan tugas dan tanggung jawab setiap unit kerja berdasarkan observasi yang dilakukan terhadap proses kerja yang dilakukan pada masing-masing unit kerja. Tujuan dari value chain analysis adalah untuk mengenali kegiatan manakah yang paling berharga bagi perusahaan dan kegiatan manakah yang dapat ditingkatkan untuk memberikan keunggulan kompetitif. Dengan demikian, dengan cara melihat ke dalam aktivitas internal perusahaan, value chain analysis dapat mengungkapkan dimana keunggulan kompetitif dan kelemahan suatu perusahaan. Misalnya, perusahaan yang bersaing menggunakan strategi diferensiasi akan berusaha untuk melakukan kegiatan berbeda yang lebih baik dari para pesaingnya. Jika perusahaan bersaing menggunakan strategi keunggulan biaya, maka perusahaan akan mencoba untuk menekan biaya aktivitas internal agar lebih rendah dari para pesaingnya. Ketika perusahaan tersebut mampu memproduksi barang dengan biaya yang lebih murah dari harga pasaran atau mampu menghasilkan produk-produk unggulan, maka perusahaan akan memperoleh keuntungan (Wijaya \& Sensuse, 2011).

Meskipun, aktivitas utama (primary activities) menambah nilai secara langsung ke proses produksi, tetapi aktivitas pendukung (support activities) juga tidak kalah penting. Saat ini, banyak perusahaan yang memperoleh keunggulan kompetitif terutama yang berasal dari peningkatan teknologi atau inovasi dalam model atau proses bisnis. Oleh karena itu, aktivitas pendukung (support activities) seperti 'sistem informasi', ' $R$ \& D' atau 'general management' biasanya merupakan sumber yang paling penting dari strategi diferensiasi. Di sisi lain, aktivitas utama (primary activities) biasanya merupakan sumber dari keunggulan biaya, dimana biaya dapat dengan mudah diidentifikasi untuk setiap proses bisnis apabila dikelola dengan baik. Gambaran aktivitas utama dan aktivitas pendukung dapat dilihat pada gambar 2 (Porter, 2011).

\section{Primary Activities}

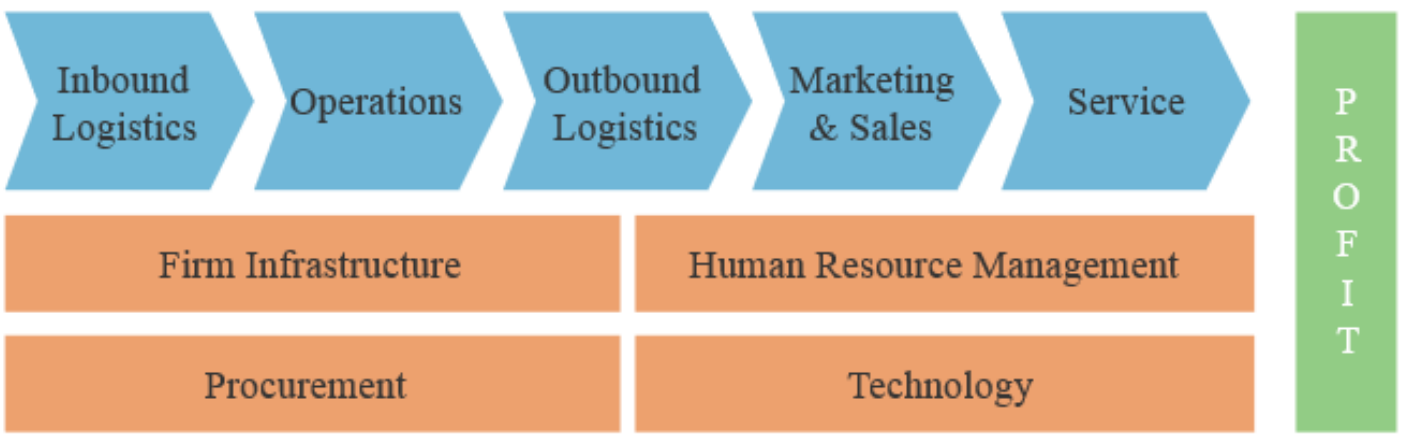

Support Activities

Gambar 2. Value Chain Model 


\subsection{Analisis SWOT}

Analisis SWOT adalah metode yang banyak digunakan dalam perencanaan strategis untuk mengevaluasi kekuatan (strengths) dan kelemahan (weaknesses) internal organisasi, serta menemukan peluang (opportunities) dan ancaman (threats) yang muncul dari luar (Wedhasmara, 2014).

Proses ini mencakup penetapan tujuan yang spesifik dari organisasi dan menemukan faktor internal serta eksternal yang mendorong dan yang menghambat dalam pencapaian tujuan tersebut. Analisis SWOT dapat dilakukan dengan cara menganalisis dan memilah-milah berbagai komponen yang dapat mempengaruhi tujuan organisasi, dan kemudian menempatkan komponenkomponen tersebut dalam matrik SWOT, di mana penerapannya adalah bagaimana agar kekuatan (strengths) yang dimiliki oleh organisasi mampu mengambil keuntungan (advantage) dari berbagai peluang (opportunities) yang tersedia dan bagaimana cara untuk mengatasi kelemahan (weaknesses) organisasi yang menghambat pengambilan keuntungan (advantage) dari peluang (opportunities). Selanjutnya, juga dibahas bagaimana kekuatan (strengths) organisasi mampu menghadapi ancaman (threats) yang muncul, dan terakhir adalah bagaimana cara mengatasi kelemahan (weaknesses) organisasi yang mampu mewujudkan ancaman (threats) menjadi nyata atau menciptakan ancaman baru (Wedhasmara, 2014). Berikut merupakan gambaran Analisis SWOT seperti pada Tabel 1.

Tabel 1. Analisa SWOT

\begin{tabular}{|l|l|l|}
\hline $\begin{array}{l}\text { Internal } \\
\text { External }\end{array}$ & Strength (S) & Weakness $(\mathbf{W})$ \\
\hline $\begin{array}{l}\text { Opportunities } \\
\text { (O) }\end{array}$ & Strategi SO & Strategi WO \\
& Menggunakan & Mengatasi \\
& kekuatan & dengan \\
& dengan & memanfaatkan \\
& memanfaatkan & peluang \\
\hline Threats (T) & peluang & Strategi WT \\
& Strategi ST & Meminimalkan \\
& Menggunakan & kelemahan dan \\
& kekuatan untuk & menghindar dari \\
& menghindar & ancaman \\
\hline
\end{tabular}

\subsection{IT Balanced Scorecard}

Balance Scorecard merupakan metrik yang diajukan oleh Kaplan dan Norton untuk mengukur kinerja manajemen atau sistem manajemen strategis dari visi dan strategi perusahaan yang diterjemahkan ke aspek-aspek penting dalam suatu bisnis (Pratiwi, Shinta, \& Riyasari, 2009).
Terdapat lima prinsip dasar bagi organisasi yang berfokuskan strategi dalam menggunakan balance scorecard, yaitu (Zizlavsky, 2014):

1. Menerjemahkan strategi ke dalam istilah operasional yang mudah dipahami dengan menggunakan balanced scorecard maupun peta strategis.

2. Menyelaraskan organisasi ke dalam strategi dengan cara menuangkan strategis pada level yang lebih tinggi ke strategis unit bisnis, departemen pendukung, dan rekan eksternal.

3. Membuat setiap personal menyusun strategi untuk menciptakan kesadaran strategis dengan menggunakan personal scorecards dengan insentif terkait.

4. Membuat strategi proses yang berkesinambungan dengan menghubungkan anggaran perusahaan dengan strategi, dan melaksanakan proses pembelajaran dan adaptasi terhadap strategi perusahaan.

5. Mobilisasi kepemimpinan untuk perubahan ke sistem manajemen strategis.

Berdasarkan pengukuran kinerja pada Balance Scorecard, Grembergen mengembangkan IT Balance Scorecard dan menjelaskan bahwa terdapat 4 perspektif pula dalam IT Balance Scorecard, yaitu (Van Grembergen \& Saull, 2001):

1. Customer orientation: menjadi pemasok pilihan untuk semua layanan informasi baik yang langsung maupun tidak langsung lewat hubungan pemasok.

2. Corporate contribution: memberikan dan meningkatkan kontribusi terhadap pencapaian tujuan bisnis melalui pemberian layanan informasi yang bernilai tambah secara efektif.

3. Operational excellence: memberikan layanan informasi yang tepat waktu dan efektif sesuai dengan target tingkat dan biaya layanan.

4. Future orientation: terus mengembangkan kemampuan internal agar dapat meningkatkan kinerja organisasi melalui inovasi, pembelajaran, dan pertumbuhan personal.

\subsection{McFarlan Strategic Grid}

McFarlan strategic grid biasa dipakai untuk memetakan sistem aplikasi berdasarkan konstribusi aplikasi tersebut terhadap organisasi. Sistem aplikasi dipetakan pada empat kuadran, yaitu: strategic, high potential, key operational, dan support. Hasil pemetaan tersebut akan menggambarkan konstribusi suatu aplikasi SI terhadap organisasi dan pengembangannya di masa mendatang. Keempat kuadran yang dimaksud dapat dilihat pada gambar 3 (Ward, Griffiths, \& Whitmore, 2002). 


\begin{tabular}{|l|l|}
\hline \multicolumn{1}{|c|}{ STRATEGIC } & HIGH POTENTIAL \\
\hline $\begin{array}{l}\text { - Applications that } \\
\text { are critical to } \\
\text { sustaining future } \\
\text { business strategy }\end{array}$ & $\begin{array}{l}\text { - Applications that } \\
\text { may be important } \\
\text { in achieving future } \\
\text { success }\end{array}$ \\
\hline $\begin{array}{l}\text { Applications on which } \\
\text { the organization } \\
\text { currently depends } \\
\text { for success }\end{array}$ & $\begin{array}{l}\text { Applications that } \\
\text { are valuable but } \\
\text { not critical to } \\
\text { success }\end{array}$ \\
\hline KEY OPERATIONAL & \multicolumn{1}{c|}{ SUPPORT } \\
\hline
\end{tabular}

Gambar 3. McFarlan Strategic Grid

\subsection{Metode Penelitian}

Tahapan penelitian ini dilakukan mulai dari:

1. Mengidentifikasi Masalah

Pada tahapan ini dilakukan kegiatan mengidentifikasi masalah apa saja yang muncul pada objek penelitian yang berkaitan dengan perencanaan strategis untuk kemudian dicari solusi yang dapat ditawarkan agar dapat mengatasi permasalahan tersebut.

2. Melakukan Studi Pustaka

Kegiatan studi pustaka dilakukan untuk mengumpulkan konsep dan teori yang dapat digunakan untuk mendukung proses penulisan penelitian ini. Konsep dan teori yang dicari berkaitan dengan perencanaan strategis SI/TI beserta beberapa analisis yang dapat dipakai untuk mendukung penyusunan rencana strategis SI/TI.

3. Mengumpulkan data

Pengumpulan data dilakukan dengan cara melakukan observasi dan wawancara ke bagian-bagian terkait.

4. Menganalisis dan menginterpretasi data

Hasil identifikasi masalah dan pengumpulan data dapat dijasikan landasan untuk melakukan analisis dan interpretasi data pada saat menyusun Perencanaan Strategis Sistem Informasi. Berikut ini tahapan analisis dan interpretasi data yang dilakukan:

1) Analisis lingkungan internal dan eksternal perusahaan menggunakan analisis SWOT

2) Analisis lingkungan internal dan eksternal SI/TI menggunakan analisis Value Chain

3) Evaluasi kinerja SI/TI menggunakan analisis IT Balanced Scorecard

4) Analisis infrastruktur yang menggambarkan infrastruktur SI/TI yang tersedia

5) Penentuan portofolio aplikasi SI/TI menggunakan McFarlan Strategic Grid

5. Menawarkan Solusi

Berdasarkan hasil analisis maka ditawarkan berbagai solusi yang dapat digunakan untuk mengembangkan strategi SI/TI pada STMIK - STIE Mikroskil yang lebih baik kedepannya yaitu pengembangan suatu Learning Management System untuk mendukung kelas jarak jauh, penyediaan informasi bisnis yang dapat mendukung perencanaan strategis yang lebih baik kedepannya, serta pengembangan aplikasi mobile sehingga berbagai informasi dapat diakses dengan lebih mudah dan efisien.

\section{PEMBAHASAN}

STMIK-STIE Mikroskil merupakan perguruan tinggi yang didirikan oleh Yayasan Bina Pertiwi. STMIK STIE Mikroskil terletak di Jl. Thamrin No 112, 124, 140 Medan, Sumatera Utara. STMIK-STIE Mikroskil merupakan perguruan tinggi yang mempunyai visi menjadi institusi pendidikan yang unggul di dalam iptek berbasis Teknologi Informasi dan Komunikasi, dan untuk mencapai visi tersebut telah dirumuskan sebanyak 4 (empat) buah misi utama yang nantinya dijadikan sebagai acuan dalam mencapai program rencana kerja secara baik dan berkelanjutan, dimana misi tersebut terdiri dari:

1. Melaksanakan Proses Belajar dan Mengajar berlandaskan Teknologi Informasi dan Komunikasi yang memenuhi Standar Nasional Pendidikan.

2. Menghasilkan sumber daya manusia yang berkualitas khususnya pada bidang Teknologi Informasi dan Komunikasi.

3. Menyiapkan sumber daya manusia yang mampu berbagi dan menyebarkan ilmu pengetahuan dalam bidang Teknologi Informasi dan Komunikasi.

4. Mengembangkan organisasi yang dapat melaksanakan tata kelola yang transparan dan akuntabel berdasarkan Teknologi Informasi dan Komunikasi.

\subsection{Analisis Value Chain}

Analisis proses bisnis dilakukan dengan menggunakan analisis value chain. Value chain ini dibagi dalam 2 kelompok, yaitu kegiatan utama dan kegiatan pendukung. Kegiatan utama meliputi:

1. Input berupa seleksi penerimaan mahasiswa baru. Proses penerimaan mahasiswa baru dilakukan setiap tahun ajaran baru untuk menjaring calon-calon mahasiswa/i yang akan diterima untuk mengikuti proses perkuliahan. 
2. Bagian operasional yang berfungsi dalam aktifitas sehari-hari untuk urusan kegiatan akademik dan kemahasiswaan. Proses perkuliahan yang dilakukan berdasarkan kurikulum yang sudah disusun sesuai dengan kebutuhan.

3. Output berupa kegiatan wisuda sarjana. Proses kelulusan bagi seluruh mahasiswa yang telah selesai mengikuti semua proses perkuliahan termasuk proses ujian.

4. Pemasaran yang meliputi pekerjaan sosialisasi institusi Pendidikan. Dalam hal ini, pemasaran harus giat mempromosikan pengimplementasian kelas jauh sebagai bagian dari strategi SI/ TI.

5. Layanan yang melayani penelitian dan pengabdian pada masyarakat.

Kegiatan pendukung meliputi:

1. Manajemen sarana dan prasarana yang melakukan perencanaan dan pengawasan terhadap keberlangsungan sarana dan prasarana di universitas.
2. Manajemen kepegawaian yang berfungsi mengurusi karyawan perguruan tinggi guna lancarnya kegiatan proses bisnis yang dimotori oleh karyawan itu sendiri.

3. Manajemen keuangan yang berfungsi mengelola keuangan perguruan tinggi.

4. Manajemen Teknologi Informasi yang bertugas menjalankan penerapan strategi SI/TI untuk keberlangsungan bisnis perguruan tinggi.

5. Manajemen kesehatan dan keamanan yang berfungsi memastikan bahwa kondisi dan situasi yang mencakup kesehatan dan keamana karyawan dan mahasiswa berjalan dengan baik.

Setiap aktivitas, baik aktivitas utama maupun aktivitas pendukung membutuhkan SI/TI dalam implementasinya untuk menjamin berjalannya proses bisnis organisasi secara baik. Berdasarkan hal tersebut maka diperlukan rancangan strategi dan tujuan SI/TI yang sejalan dengan proses dan tujuan perguruan tinggi seperti pada gambar 4 .

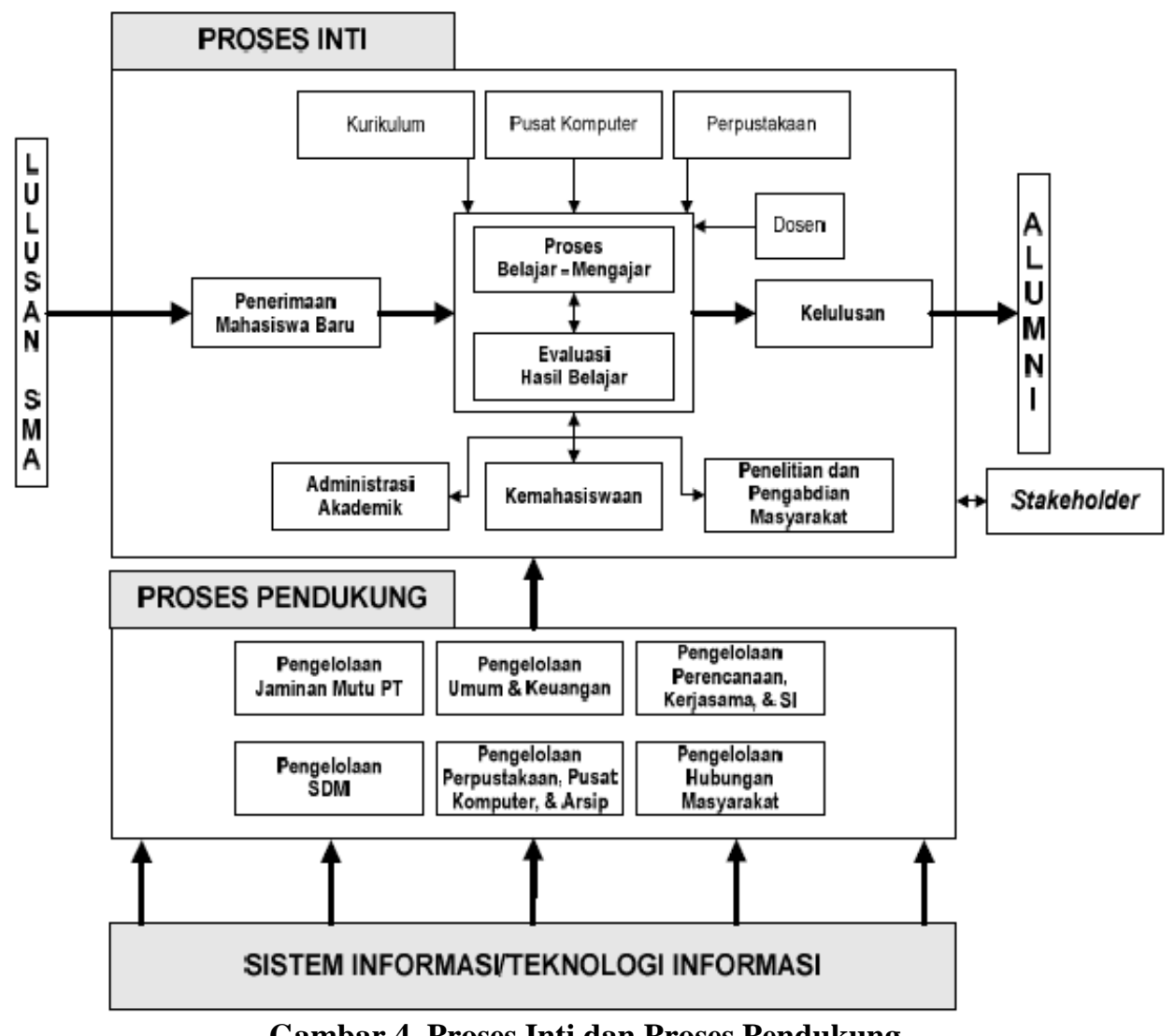

Gambar 4. Proses Inti dan Proses Pendukung

\subsection{Analisis SWOT}

Analisis SWOT dilakukan untuk menganalisis lingkungan bisnis baik eksternal maupun internal, untuk mengidentifikasi kekuatan, kelemahan, peluang, dan ancaman organisasi. Analisis SWOT dilanjutkan dengan menghitung bobot untuk mendapatkan hasil yang menggambarkan posisi organisasi. Analisis SWOT menunjukkan bahwa posisi STMIK Mikroskil berada di kuadran III, artinya lembaga tersebut menggunakan strategi untuk memanfaatkan peluang-peluang yang ada tetapi di lain pihak, lembaga berusaha meminimalkan masalah-masalah internal agar dapat merebut peluang pasar yang lebih baik. Analisis SWOT dapat dilihat pada Tabel 2. 
Tabel 2. Analisis SWOT STMIK - STIE Mikroskil

\begin{tabular}{|c|c|c|}
\hline $\begin{array}{l}\text { Internal } \\
\text { External }\end{array}$ & Strength (S) & Weakness $(\mathrm{W})$ \\
\hline $\begin{array}{l}\text { Opportunities } \\
\text { (O) }\end{array}$ & $\begin{array}{l}\text { Strategi SO } \\
\text { - Mensurvei pasar dengan cara mendistribusikan } \\
\text { kuesioner kepada mahasiswa yang ingin } \\
\text { melanjutkan kuliah dengan keterbatasan waktu } \\
\text { - Melakukan sosialisasi ke sekolah- sekolah } \\
\text { menengah atas untuk menjaring calon mahasiswa } \\
\text { baru } \\
\text { - Mengadakan sosialisasi dan event-event bertema } \\
\text { pendidikan } \\
\text { Meningkatkan fasilitas baik sarana dan prasarana } \\
\text { dalam bidang teknologi secara up to date dan } \\
\text { pengenalan teknologi yang digunakan untuk } \\
\text { mendukung perkuliahan }\end{array}$ & $\begin{array}{l}\text { Strategi WO } \\
\text { - Merapikan proses bisnis yang sekarang } \\
\text { (as-is) dengan misi Perguruan tinggi } \\
\text { dengan mendukung layanan yang ada } \\
\text { yaitu penelitian dan pengabdian pada } \\
\text { masyarakat sekaligus menaikkan derajat } \\
\text { status lembaga (dari Perguruan Tinggi ke } \\
\text { Perguruan Tinggi berskala internasional) } \\
\text { - Memperbaiki dan melakukan improvisasi } \\
\text { terhadap LMS untuk mendukung proses } \\
\text { perkuliahan jarak jauh } \\
\text { - Peningkatan bandwidth } \\
\text { mempercepat akses informasi } \\
\text { - Pengadaan pelatihan secara berkala untuk } \\
\text { peningkatan kualitas SDM dosen dan } \\
\text { civitas akademika }\end{array}$ \\
\hline Threats (T) & $\begin{array}{l}\text { Strategi ST } \\
\text { - Mempunyai branding kuat sebagai lembaga } \\
\text { Pendidikan yang menitik beratkan kepada } \\
\text { keunggulan IS/ IT guna menonjolkan } \\
\text { keunggulannya dari para lembaga pesaing } \\
\text { - Pemberian bantuan beasiswa bagi mahasiswa } \\
\text { berprestasi dan mahasiswa kurang mampu }\end{array}$ & $\begin{array}{l}\text { Strategi WT } \\
\text { - Melakukan promosi yang berfokus pada } \\
\text { kelas jauh (on-line learning) dengan } \\
\text { menjabarkan keuntungan-keuntungan } \\
\text { yang diraih bagi pelanggan (mahasiswa). } \\
\text { - Bekerja sama dengan perusahaan } \\
\text { perusahaan yang membutuhkan tenaga } \\
\text { ahli yang dihasilkan oleh perguruan tinggi } \\
\text { - Membuat dokumen tata kelola yang baik } \\
\text { dan jelas }\end{array}$ \\
\hline
\end{tabular}

\subsection{Analisis IT Balanced Scorecard}

Sebelum menganalisa divisi TI, penyelarasan visi, misi, dan strategi STMIK Mikroskil harus dilakukan. Hasilnya adalah pemetaan perspektif TI dan Balanced Scorecard seperti pada Tabel 3.

Tabel 3. Analisis IT Balanced Scorecard

\begin{tabular}{|c|c|c|}
\hline IT BSC & Strategi & Tujuan Strategi \\
\hline $\begin{array}{l}\text { Kontribusi } \\
\text { Organisasi }\end{array}$ & $\begin{array}{l}\text { Ketersediaan infrastruktur jaringan dan sistem informasi } \\
\text { yang tepat }\end{array}$ & Meningkatkan kontribusi fungsi TI \\
\hline $\begin{array}{l}\text { Orientasi } \\
\text { Pengguna }\end{array}$ & $\begin{array}{l}\text { - Memelihara dan mengembangkan sistem informasi } \\
\text { dan sumber daya infrastruktur. } \\
\text { - Memastikan penyediaan data dan informasi yang } \\
\text { lengkap, cepat, dan akurat. }\end{array}$ & $\begin{array}{l}\text { - Kerjasama pengguna } \\
\text { - Meningkatkan kepuasan pengguna } \\
\text { - Meningkatkan kemampuan pengguna } \\
\text { - Meningkatkan produktivitas pengguna }\end{array}$ \\
\hline $\begin{array}{l}\text { Penyempurnaan } \\
\text { Operasional }\end{array}$ & $\begin{array}{l}\text { - ketersediaan infrastruktur jaringan dan sistem } \\
\text { informasi yang tepat. } \\
\text { - memiliki kompetensi sumber daya manusia yang } \\
\text { tinggi. } \\
\text { - memelihara dan mengembangkan sistem informasi } \\
\text { dan sumber daya infrastruktur. } \\
\text { - memastikan penyediaan data dan informasi yang } \\
\text { lengkap, cepat, dan akurat. }\end{array}$ & $\begin{array}{l}\text { - manajemen masalah } \\
\text { - efisiensi operasional } \\
\text { - efisiensi pengembangan aplikasi } \\
\text { - kinerja staf TI }\end{array}$ \\
\hline $\begin{array}{l}\text { Orientasi Masa } \\
\text { Depan }\end{array}$ & $\begin{array}{l}\text { - memiliki kompetensi sumber daya manusia yang } \\
\text { tinggi. } \\
\text { - memelihara dan mengembangkan sistem informasi } \\
\text { dan sumber daya infrastruktur. }\end{array}$ & $\begin{array}{l}\text { - mengembangkan sistem dan infrastruktur } \\
\text { TI } \\
\text { - meningkatkan kemampuan karyawan } \\
\text { - meningkatkan kemampuan sistem }\end{array}$ \\
\hline
\end{tabular}

Pengukuran dilakukan dengan mengidentifikasi perspektif dan menghasilkan hasil pencapaian tujuan. Bobot pengukuran yang ditentukan sangat buruk (0\% -54\%), buruk (55\% - 64\%), cukup (65\% - 74\%), bagus (75\% - 84\%), sangat baik $(85 \%-100 \%)$. Di bawah adalah evaluasi dari kinerja departemen IT yang ditampilkan dalam Tabel 4. 
.Tabel 4. Evaluasi Kinerja Departemen TI

\begin{tabular}{|c|c|c|c|}
\hline Perspektif & Tujuan Strategi & Hasil & Identifikasi \\
\hline \multirow[t]{2}{*}{$\begin{array}{l}\text { Kontribusi } \\
\text { Organisasi }\end{array}$} & $\begin{array}{c}\text { Meningkatkan } \\
\text { kontribusi fungsi } \\
\text { TI }\end{array}$ & $93 \%$ & Sangat baik \\
\hline & Rata-rata & $93 \%$ & $\begin{array}{c}\text { Sangat } \\
\text { baik }\end{array}$ \\
\hline \multirow[t]{5}{*}{$\begin{array}{l}\text { Orientasi } \\
\text { Pengguna }\end{array}$} & $\begin{array}{c}\text { kerja sama } \\
\text { pengguna }\end{array}$ & $83 \%$ & Bagus \\
\hline & $\begin{array}{c}\text { meningkatkan } \\
\text { kepuasan } \\
\text { pengguna }\end{array}$ & $88 \%$ & Sangat baik \\
\hline & $\begin{array}{c}\text { meningkatkan } \\
\text { kemampuan } \\
\text { pengguna }\end{array}$ & $85 \%$ & Sangat baik \\
\hline & $\begin{array}{c}\text { meningkatkan } \\
\text { produktivitas } \\
\text { pengguna } \\
\end{array}$ & $82 \%$ & Bagus \\
\hline & Rata-rata & $84.5 \%$ & Bagus \\
\hline \multirow[t]{5}{*}{$\begin{array}{c}\text { Penyempurnaan } \\
\text { Operasional }\end{array}$} & $\begin{array}{c}\text { manajemen } \\
\text { masalah }\end{array}$ & $72 \%$ & Cukup \\
\hline & $\begin{array}{c}\text { efisiensi } \\
\text { operasional }\end{array}$ & $86 \%$ & Sangat baik \\
\hline & $\begin{array}{c}\text { efisiensi } \\
\text { pengembangan } \\
\text { aplikasi } \\
\end{array}$ & $89 \%$ & Sangat baik \\
\hline & Kinerja staf TI & $90 \%$ & Sangat baik \\
\hline & Rata-rata & $84.25 \%$ & Bagus \\
\hline \multirow[t]{4}{*}{$\begin{array}{c}\text { Orientasi Masa } \\
\text { Depan }\end{array}$} & $\begin{array}{c}\text { mengembangkan } \\
\text { sistem dan } \\
\text { infrastruktur TI } \\
\end{array}$ & $84 \%$ & Bagus \\
\hline & $\begin{array}{c}\text { meningkatkan } \\
\text { kemampuan } \\
\text { karyawan } \\
\end{array}$ & $91 \%$ & Sangat baik \\
\hline & $\begin{array}{c}\text { meningkatkan } \\
\text { kemampuan } \\
\text { sistem }\end{array}$ & $87 \%$ & Sangat baik \\
\hline & Rata-rata & $\mathbf{8 7 . 3 3 \%}$ & $\begin{array}{c}\begin{array}{c}\text { Sangat } \\
\text { baik }\end{array} \\
\end{array}$ \\
\hline & Nilai Rata-rata & $\mathbf{8 5 . 8 3 \%}$ & $\begin{array}{c}\text { Sangat } \\
\text { baik }\end{array}$ \\
\hline
\end{tabular}

\subsection{Analisis Infrastruktur}

Infrastuktur yang tersedia saat ini di STMIK STIE Mikroskil sebagai berikut:

1. Server yang beroperasi 24 jam sebanyak 2 unit Server adalah suatu komputer yang berfungsi menjadi pusat dan pengelola komputer lainnya. Karena berfungsi sebagai pusat, sebuah server harus memiliki beberapa spesifikasi yang lebih unggul dibandingkan dengan komputer yang terhubung ke dalam suatu jaringan.

2. Komputer Client (untuk keperluan laboratorium maupun komputer staf) sebanyak 658 unit

Komputer client adalah komputer yang meminta satu layanan tertentu kepada komputer server. Komputer client harus dilengkapi dengan aplikasi khusus agar dapat memformat permintaan ke komputer server dan kemudian layanan dari komputer server dapat diterima dan digunakan.
3. Printer sebanyak 55 unit

Printer di gunakan untuk mencetak data, di dalam jaringan printer dapat digunakan secara bersamasama (printer sharing)

4. Switch sebanyak 56 unit

Switch merupakan perangkat keras untuk menghubungkan antar jaringan komputer yang mempunyai protokol yang sama. Terdapat dua jenis arsitektur dasar yang digunakan pada switch yaitu cut-through dan store and forward. Switch cutthrough mempunyai keunggulan dari segi kecepatan karena switch hanya mengecek alamat tujuan suatu paket sebelum paket tersebut diteruskan ke tujuannya, sedangkan switch store and forward menggunakan mekanisme yang berbeda. Switch ini akan menerima dan mengecek seluruh isi paket sebelum mengirimkannya ke alamat tujuan. Akibatnya, untuk memeriksa seluruh paket tersebut merlukan banyak waktu, namun proses ini memiliki keunggulan yaitu switch dapat mengetahui adanya paket data yang rusak dan mencegahnya mengganggu jaringan.

5. Modem sebanyak 28 unit

Digunakan oleh jaringan agar dapat terhubung ke internet

6. NIC (Network Internet Card) atau kartu jaringan sebanyak 668 unit

NIC merupakan hardware untuk mendukung jaringan komputer yang berfungsi untuk menghubungkan komputer yang satu dengan yang lainnya.

7. $H u b$ sebanyak 76 unit

$H u b$ merupakan perangkat keras untuk keperluan jaringan yang dapat digunakan sebagai terminal port yang menghubungkan komputer dalam jaringan. $\mathrm{Hub}$ memiliki sejumlah port RJ45 dimana jumlah port minimal dalam sebuah $h u b$ adalah 4 port.

8. Kabel UTP

Kabel UTP merupakan kabel jaringan dengan 8 kabel warna-warni di dalamnya yang berfungsi untuk menghubungkan komputer yang satu dengan lainnya dalam jaringan.

9. Konektor RJ45

Konektor RJ45 merupakan konektor yang digunakan untuk menghubungkan kabel UTP. Konektor RJ45 biasanya memiliki 8 pin di dalamnya yang dipasang sesuai dengan kabel UTP.

10. Front-End Processor

Front-end processor mengelola dan mengoordinasikan komunikasi serta lalu lintas data yang masuk dan keluar pada host komputer. Frontend processor bertugas untuk mengumpulkan pesanpesan yang masuk dari host komputer dan kemudian menyediakan data bagi host komputer. Tugas lainnya adalah menerima permintaan-permintaan untuk transmisi ke terminal.

11. Jaringan kabel dan wireless

12. Sistem Operasi yang digunakan: Windows 8.1, Windows 10 
13. Aplikasi yang digunakan: Microsoft Office 2016, Adobe Photoshop CS6, Microsoft Visual Studio 2015, Microsoft SQL Server 2014

\subsection{Portofolio Aplikasi}

Pemetaan aplikasi portofolio menggunakan McFarlan Strategic Grid. Pemetaan ini berguna untuk mengidentifikasi kategori aplikasi, sehingga pertimbangan aplikasi mana yang memberikan kontribusi IT dan aplikasi mana yang sangat penting untuk kegiatan operasional dapat dijelaskan. Pemetaan portofolio dapat dilihat dalam Tabel 5.

Tabel 5. Pemetaan Aplikasi Portofolio

\begin{tabular}{|c|c|}
\hline Strategi & Potensi Tinggi \\
\hline 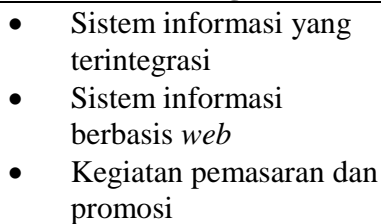 & 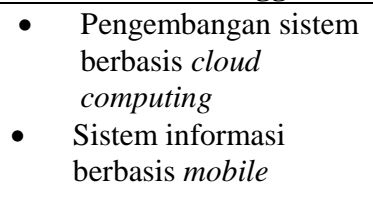 \\
\hline $\begin{array}{ll}\text { - } & \text { Learning Management } \\
& \text { System } \\
\text { - } & \text { Aplikasi Alumni } \\
\text { - } & \text { Form elektronik } \\
\text { - } & \text { Aplikasi Penelitian dan } \\
& \text { Pengabdian kepada } \\
\text { Masyarakat }\end{array}$ & $\begin{array}{ll}\text { - } & \text { Internet } \\
\text { - } & \text { Website STMIK - STIE } \\
\text { Mikroskil } \\
\text { - } \quad \text { Media sosial seperti } \\
\text { Facebook, Twitter, } \\
\text { Instagram }\end{array}$ \\
\hline Kunci Operasional & Dukungan \\
\hline
\end{tabular}

\subsection{Solusi Yang Ditawarkan}

Beberapa solusi yang dapat ditawarkan dalam perencanaan strategis ini yaitu:

1. Manajemen Pembelajaran

Manajemen pembelajaran diusulkan untuk meningkatkan kinerja mahasiswa dan karyawan dengan kemudahan uang, waktu. dan tempat. Dengan belajar manajemen, mahasiswa bisa belajar tepat pada waktunya (langsung). Bahan belajar yang bersangkutan dengan proses konferensi dengan video, forum dan tugas yang diberikan melalui LMS.

Learning Management adalah aplikasi perangkat lunak berbasis web untuk merencanakan, menerapkan, menilai proses pembelajaran atau layanan yang dikembangkan untuk pengiriman, melacak, melaporkan dan menetapkan konten pembelajaran (Buendia, Agusti, Benlloch, Bisbal, \& Lluesma, 2004). Kelebihan pengelolaan pembelajaran bagi pengguna adalah mereka bisa melakukan pembelajaran mandiri sehingga menghemat waktu dan biaya, sekaligus fleksibel, artinya sistem bisa diakses kemana-mana dan setiap asalkan terhubung dengan internet.

2. Business Information

Informasi bisnis diusulkan untuk membatasi waktu untuk analisis dan membuat keputusan yang lebih baik, akurat, dan tepat waktu. Saat ini, STMIK STIE Mikroskil masih melakukan analisis secara manual dan akibatnya kesalahan dalam analisis dapat terjadi. Untuk solusi, informasi bisnis mampu memberikan informasi yang akurat dan tepat waktu terkait dengan statistik mahasiswa dan pembelajarannya sehingga akan mendukung keputusan dalam merencanakan pengembangan sistem, pelayanan terhadap mahasiswa, penilaian akademis dalam pembelajaran, dan sebagainya. Dengan menerapkan Informasi bisnis, pengembangan gudang data yang memudahkan integrasi aplikasi, menunjukkan pengambilan data operasional, data eksternal, flat file, kemudian diekstrak, ditransformasikan, dan dimasukkan ke dalam data warehouse tercapai. Kecerdasan bisnis bisa dilihat di dashboard sehingga bisa diakses lebih cepat, dan didukung keputusan yang akurat.

Business Information menggabungkan arsitektur, alat, database, alat analisis, aplikasi, metodologi untuk memungkinkan akses data interaktif, menggunakan data, melakukan analisis yang sesuai. Business Information adalah arsitektur organisasi pengumpulan operasional terpadu serta aplikasi untuk mendukung keputusan dan database yang memberikan kemudahan akses data sehingga dapat membantu dalam pengambilan keputusan yang akurat (Turban, E. Aronson, \& Liang, 2007).

Menggunakan Informasi bisnis memberi nilai bagi organisasi, seperti; mengkonsolidasikan data dalam satu platform dan menyebarluaskan informasi yang berguna untuk organisasi, memberikan pelaporan yang mendalam, menyediakan fasilitasi penyesuaian antar muka untuk ekspektasi pengguna, meminimalkan kesalahan operasional dari pengguna, biaya tidak terlalu tinggi, databank fleksibel, dan responsif (Turban et al., 2007). Ketiga konsep Informasi bisnis tersebut mengilhami peneliti dalam mengembangkannya.

3. Aplikasi Mobile

Aplikasi mobile ini diperuntukan ke mahasiswa guna mempermudah proses belajar mengajar dimanapun mahasiswa berada tanpa harus buka laptop dan koneksi ke internet terlebih dahulu. Mahasiswa akan cepat dapat mengisikan forum sebagai tugas mingguan guna berinteraksi dengan semua mahasiswa dalam kelasnya termasuk dosen pengajar.

Antarmuka aplikasi mobile berbasis pada konsep web, terdiri dari header, menu, content, footer. Antarmuka ini selaras dengan lapisan ponsel pada platform blackberry, iphone, android, dan windows. Aplikasi mobile adalah aplikasi yang bisa dijalankan meski pengguna berpindah dengan menggunakan alat (mobile), biasanya dikelompokkan berdasarkan platform. Dengan menggunakan aplikasi Mobile, pengguna akan mudah mengakses informasi kapan saja, berkomunikasi secara real time, mengelola masyarakat, dapat memberikan informasi langsung 
kepada pengguna, tidak bergantung pada internet, mudah dan ramah.

4. Analisis Gap

Analisis Gap berguna untuk mencari cara memenuhi kebutuhan informasi bisnis mendatang dengan membandingkan kebutuhan informasi bisnis pada masa mendatang dan kemampuan sumber daya SI/TI yang dimiliki organisasi pada saat ini, kemudian mencari gap di antara keduanya. Kebutuhan informasi yang masih belum bisa dipenuhi pada saat ini ataupun yang masih perlu peningkatan kualitas merupakan target utama bagi kegiatan perencanaan strategis SI/TI untuk dicarikan pemenuhannya. Analisis Gap menghasilkan berbagai efek yang ditimbulkan karena adanya kesenjangan antara kondisi yang seharusnya ada, dibandingkan dengan kondisi yang ada saat ini. Hasil analisis gap yaitu sebagai berikut.

1) Informasi yang ada seharusnya dapat digunakan dalam kegiatan pengambilan keputusan.

2) Aplikasi mobile yang sudah tersedia namun belum dikembangkan dengan baik dan kurang efektif dan efisien

3) Knowledge management yang bisa lebih dioptimalkan

4) Aplikasi manajemen perkuliahan yang lebih bisa ditingkatkan efisiensinya

\section{KESIMPULAN}

Dari hasil analisis yang dilakukan terhadap berbagai data yang diperoleh di lapangan maupun dari hasil studi pustaka yang dianalisis menggunakan kerangka kerja Ward and Peppard, dapat disimpulkan bahwa perencanaan strategis sistem informasi pada STMIK - STIE Mikroskil dapat digunakan untuk menyelaraskan antara kebutuhan strategi bisnis, dan strategi SI/TI untuk menghasilkan nilai tambah bagi organisasi dalam bentuk peningkatan keunggulan kompetitif. STMIK - STIE Mikroskil direkomendasikan untuk membuat perencanaaan strategi IT dan IS secara lebih detail dan cermat melalui pelaksanaan model sumber dan pengiriman yang efektif yang didukung oleh organisasi TI yang lebih terpusat sesuai dengan hasil evaluasi kinerja departemen TI yang sudah tergolong baik sehingga departemen TI mampu mengembangkan sistem yang dipakai saat ini menjadi lebih baik lagi, merasionalisasi basis infrastruktur saat ini, mengurangi beban perawatan \& peningkatan; kembali fokus pada nilai tambah (value added) bagi perusahaan dan stakeholder. Selain itu juga dapat mengoptimalkan fungsi TI berdasarkan proses praktik terbaik (best practices process / ITIL) yang dikirimkan ke bisnis dalam mode pengalihan Service Letter Agreement (SLA) yang diformalkan untuk service yang bisa dialihkan dan dikelola melalui IT outsourcing, memanfaatkan (Leverage) dan menggunakan kembali (Reuse) apa yang sudah sukses dalam bisnis, menentukan solusi TI secara umum (general), memanfaatkan praktik terbaik dan solusi umum, mengembangkan berbagai solusi sesuai dengan kunci operasional dan potensi tinggi yang dimunculkan dalam portofolio aplikasi serta memanfaatkan berbagai sumber dukungan yang telah dimiliki saat ini.

Keselarasan antara strategi IS /IT dengan strategi bisnis adalah mutlak serta komunikasi yang dibangun secara intensif oleh kepala bagian teknologi agar terjalin hubungan yang baik dengan jajaran pimpinan yang lain agar mendapat dukungan dan "buy in" dari leadership sebuah perguruan tinggi.

\section{SARAN}

Beberapa saran yang dapat diberikan berkaitan dengan laporan dan penelitian ini yaitu perencanaan strategis ini dapat dilakukan dengan menggunakan framework yang berbeda dan melengkapi metodemetode analisis yang belum digunakan pada perencanaan strategis ini sehingga mendapatkan berbagai hasil analisis yang dapat mendukung pengembangan sistem yang lebih sesuai dengan perkembangan zaman serta hasil yang didapatkan lebih akurat dan terpercaya.

\section{DAFTAR PUSTAKA}

Anitasari, P. 2016. Perencanaan Strategi Sistem Informasi Dalam Meningkatkan Daya Saing Sekolah Pada SMK Komputer Mandiri Banjarbaru. Jurnal Bianglala Informatika.

Buendia, F., Agusti, M., Benlloch, J., Bisbal, E., \& Lluesma, M. 2004. XEDU, A Proposal of Learning Management System Implementation. Journal of Information Technology Impact, 4(1), 55-66.

Fariani, R. I. 2014. Analisa Perencanaan Strategi Sistem Informasi Dan Teknologi Informasi (SI/TI) Dengan Menggunakan Framework Ward \& Peppard Di Perguruan Tinggi ABC. Seminar Nasional Sistem Informasi Indonesia.

Faslah, R., \& Haris, A. 2017. Perencanaan Strategis Sistem Informasi. Jurnal ELTIKOM. https://doi.org/10.31961/eltikom.v1i1.4

Porter, M. E. 2011. Competitive Advantage of Nations: Creating and Sustaining Superior Performance. In Strategic Management.

Pratiwi, I., Shinta, H., \& Riyasari, D. 2009. Pengukuran Kinerja Perusahaan Dengan Metode Balanced Scorecard. Financial Analytics: Problems and Solutions, (25), 28-34.

Setiawan, A. B., Rosidi, A., \& Boedijanto, E. 2014. Perencanaan Sistem Informasi Strategis Di Dinas Kesehatan Kabupaten Kediri. NUSANTARA of RESEARCH, 01(2), 105-115.

Susena, E., Utami, E., \& Sunyoto, A. 2015. Perencanaan Strategis Sistem Informasi Smart Campus Untuk Meningkatkan Pelayanan di Politeknik Indonusa Surakarta. Jurnal Sainstech Politeknik Indonusa Surakarta. 
Turban, E., E. Aronson, J., \& Liang, T.-P. 2007. Decision Support Systems and Business Intelligence. Decision Support and Business Intelligence Systems, 7/E. https://doi.org/10.1017/CBO9781107415324.004

Van Grembergen, W., \& Saull, R. 2001. Aligning business and information technology through the balanced scorecard at a major canadian financial group: Its status measured with an IT BSC maturity model. Proceedings of the Hawaii International Conference on System Sciences. https://doi.org/10.1109/HICSS.2001.927176

Ward, J., Griffiths, P. M., \& Whitmore, P. 2002. Strategic Planning for Information Systems (3rd ed.). Chichester: Wiley.

Ward, J., \& Peppard, J. 2002. Success Factors in Strategic Information Systems. In Strategic Planning for Information Systems. https://doi.org/10.1016/0024-6301(90)90122-K

Wedhasmara, A. 2014. Langkah-Langkah Perencanaan Strategis Sistem Informasi dengan Menggunakan
Metode Ward and Peppard. Jurnal Sistem Informasi.

Wijaya, A., \& Sensuse, D. I. 2011. Perencanaan Strategis Sistem Informasi Dan Teknologi Informasi Pada Perusahaan Otomotif Dengan Menggunakan Metodologi Tozer. Jurnal Inovasi Dan Kewirausahaan, 17-18.

Wijiyanto, \& Purwanto, E. 2015. Perencanaan Sistem Informasi Strategis Pendidikan di Perguruan Tinggi Swasta Kota Surakarta. DutaCom Journal, $8(1)$. https://doi.org/10.1017/CBO9781107415324.004

Zizlavsky, O. 2014. The balanced scorecard: Innovative performance measurement and management control system. Journal of Technology Management and Innovation. https://doi.org/10.4067/S071827242014000300016 